\title{
AN ANALYSIS OF GRAMMATICAL ERRORS IN SPEECH AT THE STUDENTS OF ENGLISH EDUCATION STUDY PROGRAM OF MUHAMMADIYAH UNIVERSITY OF METRO ACADEMIC YEAR 2013/2014
}

\author{
BY \\ Septian Dwi Sondiana \\ Sudirman AM
}

The objectives of the research are to find out the types of grammatical errors in English students' speech; to find out the percentage of grammatical errors in English students' speech; to find out the factors influencing English students' grammatical errors in their speech. Based on the data, the students have problem in producing verb group, errors in subject-verb agreement, errors in the use of articles, errors in the use of prepositions, errors in noun pluralization, errors in the use of pronouns, and errors in the use of conjunctions. It shows that Anisa made eleven sentences in 2 minutes 28 seconds. She made eight errors. Dewi made seven sentences in 1 minutes 57 seconds. She made five errors. Fatika made sixteen sentences in 4 minutes 14 seconds. She made eight errors. Fitri made sixteen sentences in 4 minutes 23 seconds. She made seven errors. Ibnu made ten sentences in 2 minutes 18 seconds. He made eight errors. Linda made fiveteen sentences in 3 minutes 7 seconds. She made eight errors. Musli made fourteen sentences in 2 minutes 39 seconds. She made six errors. Nyoman made twelve sentences in 3 minutes 43 seconds. He made nine errors. Pera made ten sentences in 2 minutes 23 seconds. She made seven errors. Sri made fourteen sentences in 6 minutes 34 seconds. She made eleven errors. And about the percentages of errors, here is the data; Anisa: $72,73 \%$ of errors; Dewi: $71,4 \%$ of errors; Fatika: $50 \%$ of errors; Fitri: $43,75 \%$ of errors; Ibnu: $80 \%$ of errors; Linda: 53,3\% of errors; Musli: 42,8\% of errors; Nyoman: $75 \%$ of errors; Pera: $70 \%$ of errors; Sri: $78,57 \%$ of errors. Based on interview, it shows it can be concluded the factors influence of English students' grammatical errors in their speech when their speak using grammar rule. The internal factors are; The first, the students are still difficult to make feeling, for example; confident, feel scary, when they are speaking in public. The second, the students are not mastered in their skills. The third, the students are not have many vocabulay, so they can not express their idea to speak. The forth, the students are still think that grammar are not important to speak. For the external factors are; the first, the student can not express their speaking because of their environment or comunity. The second, the teaching-learning process.

Key words: An Analysis, Grammatical Errors, in Speech

Speaking skill is seen as somewhat

difficult for some language learners.
Richards (2008:19) states that a speaker

should at least pronounce the words 
well, choose the suit dictions, and try to do grammatically correct though, perhaps in any cases, it is common when a speaker speaks without having good attention at accuracy or fluency.

Setiyadi (2006:12) states that the points out that English tends to be very difficult to be learnt by Indonesian learners because the Indonesian language has no tenses that are similar to the tenses of English. It can be said that the Indonesian students have difficulties when they learn English, especially in using tenses.

Based on pre survey at sixth semester of Muhammadiyah University of Metro academic year 2013/2014, the researcher found some students problem in speaking: (1) the students still have difficulties in their speaking. (2) the students' still have difficulties to pronounce sentences well. (3) the students' grammatical mastery are still low. (4) the students' vocabulary mastery are still low.

The researcher proves the statement based on pre survey video recorded. The researcher has recorded one of students at sixth semester of Muhammadiyah University of Metro academic year 2013/2014 as a sample when they were speech in public speaking class. The researcher is sure that there are many grammatical error are found in students' speaking. Look at the sample below.

"Do you remember guys, the first time you saw magic? When I little kids, my kindergarten teacher show me a trick. ((pause)) She did this performing, 'Hi kids, look at this handkerchief. I push in this blue handkerchief into my hand and watch, it's gone.' But if you say ((pause)) magic word abrakadabra, 
you can make it repair. ((pause)) Pak

ulangi ya pak."

Based on transcript above, researcher has to compare the sentences students produce with what seems to be normal or correct sentences in the target language which correspond with them to identify errors. For example: When I little kids, my kindergarten teacher show me a trick. It is not difficult to see that the correct sentence should be: When I was a little kid, my kindergarten teacher showed me a trick. In the sentence, the student is doing error in sentence. That is omission of verb in past tense. The problems may be caused by several reasons such as: The students are low in grammar and vocabulary mastery. For the vocabularies problem, it is proved in the last sentence. She said "ulangi ya pak". It means she cannot produce good vocabularies.
In this research, researcher wants to analyze the grammatical error, so the researcher can concludes that grammatical errors are the patterns of arrangement of words in sentences and the pattern of arrangement of parts of words into words that are not appropriate with the pattern and rules that have been determined in a language that is being used. Setiyadi $(2006: 12)$ states that vocabulary is one of problem that influence the speaking ability. Learner should be have many vocabularies to speak well.

The researcher is sure that there are some grammatical errors in speaking. The researcher is interested in doing survey on this topic and find out if there are any tenses errors in speech related with the title of this research “An Analysis of Students' English Grammatical Error in Their Speech at Sixth Semester of Muhammadiyah 
University of Metro Academic Year 2013/2014”.

Corder (2003:10-11) explains that there are four categories of error those are omitting element which should be, adding element which not should be, incorrect choice, and incorrect structure.

First category is omitting element which should be there in sentence. E.g. in English, there are two elements that should be there in a sentence those are subject and predicate. If there is no one of element, so the structure sentence doesn't have complete structure and can't be categorized as a sentence.

(1) According to Siswanto (2002: 199) states that training is...... Example above doesn't have subject, it should be:

(1a) Siswanto (2002: 199) states that training is....
Second category is adding element that shouldn't be there. E.g. there are two predicates or subjects in a sentence which has one main clause. Structure below has two predicates; is used and is.

(2) Method type is used in this thesis is...

To show that the structure (2) above has two predicates, it showed an example that structured based on structure above:

(2a) Method type which is used in this thesis is....

Element which in structure (2a) must be there, besides if the first is is omitted until verb used be past participle used

(2b) Method type used in thesis is.... So, structure (2a) and (2b) above can be a sentence that has correct rule in English grammatical.

Third category is incorrect choice. 
To explain this category let see this example:

(3) In this study the sample were divided into...

Incorrect choice is in were that should be was because the subject is singular. Second alternative is sample, this word can be moved to plural that is samples because the predicate is were divided into...

The last category is incorrect structure. Let see this example:

(4) Type method used in this research is...

Example above can be moved to:

(4a) Method type used in this research is...

Many researchers use the linguistic category taxonomy as a reporting tool which organizes the errors they have collected. Although some use it as the only classification on scheme offered, many use it to add to the description of errors provided by other taxonomies. For example, if researcher has classified their errors as interlingua and developmental, they often additionally report the linguistic categories into which these major error type fall, e.g. developmental errors in the auxiliary, in the noun phrase, in the complement system; interlingua errors in phonology, in word order, and in vocabulary. We present below the results of two error analyses that used linguistic category as the primary classification scheme.

Politzer and Ramirezin Adib (2012:21) studied 120 MexicanAmerican children learning English in the United State, taping their narrative of a short, silent animated cartoon. Errors were extracted for analysis from this body of natural speech.

So, the researcher can conclude that category of error are ommiting 
component which should be, totaling division which not should be, incorrect choice and incorrect sructure and category of error were removed for analysis from frame of speech.

\section{METHOD}

In conducting this research, the method ofthis research is qualitative research. Sugiyono, (2008:92) states that qualitative research is the research method based on positive phylosophy. It is used to research object condition naturally where the researcher is a key of instrument. The term of naturalistic shows that the research is natural, on the normal situation without manipulate the condition, emphasize on the natural description. The process of taken data or phenomena called as taking of the data naturally.Cohen, L. (2007:168) states that qualitative research has some purposes, are; describing, and reporting the creation of key concepts, theory generation and testing. Besides, this research also can be called as qualitative research type descriptive. Arikunto (2007:234) states that descriptive research hasn't purpose to test the certain hypothesis, but just describes some variable and condition naturally. So, that can be conclude qualitative research is the method that used to object condition naturally without manipulate the condition

In this research, the researcher intends to find out the kinds of grammatical errors are made by the students. The first, the researcher collects the data from observation and interview with the student naturally. And then, those the researcher analyze the students' grammatical errors in their speech and possible causes of those errors 
from the data because make the research more clear to analyze and describe the entire problem happened in students' speech. In this research, the researcher classified the errors based on Traditional Descriptive Taxonomy.

Thus, descriptive qualitative method in this research has purpose to describe about the students' English grammatical error in their speech at sixthsemester of Muhammadiyah University of Metro Academic Year 2013/2014 systematically and accurately based on the reality.

\section{FINDING}

This research was carried out at Muhammadiyah University of Metro on $8^{\text {th }}$ May 2014 which located in on Jl. Ki. Hajar Dewantara No. 116 Kota Metro-Lampung as the location of the research. The research design of this research is qualitative research. This research was intended to find out English students' grammatical errors in speech at sixth semester of Muhammadiyah University of Metro academic year 2013/2014. In this research the researcher focused on setting description, when got the data the researcher preparation was the first step in doing research. As the first step in doing the research, the researcher gave the permission letter to the English department faculty. After the researcher got the response, so the researcher began to do a research.

The researcher did data collection in the whole students in Muhammadiyah University of Metro at sixth semester which became as the sample of this research. In this research, the first time the researcher did an observation. After doing the observation, the researcher knew about the grammatical errors in 
speech from data of recording speech. The second, the researcher got persentages of grammatical errors from each students. The third, researcher used interview, the researcher used the instrument to support data analyze students in grammatical errors in speech, the factors that influece their grammatical error in speech.

From the analysis result above, it can be concluded that the students have not mastered the use of verb groups. We can see it from the number of the errors made. Although they had been taught about it before, they were still confused which one to use when making a grammatical sentence. It could be because in Bahasa Indonesia we do not have the verb conjugations. We do not have time signaling in expressing ideas. They are unfamiliar to this form and because English is still foreign for them. And those are the possible causes of their errors. The students were still confused in making the agreement between subject and verb. It could be because in Bahasa Indonesia there is no agreement between subject and verb. The students were still confused in differentiating whether to use the definite or indefinite articles. It could be because in Indonesian language grammar there is no definite article used. The students still confused in deciding preposition which preposition should be used, whether to use in, on, or at.

The students over generalized the pluralizing of nouns. They just added the $-\mathrm{s} /$-es without considering that there are some irregular forms of nouns pluralization. The students still confused in deciding which pronoun should be used to substitute nouns, whether it is personal, relative, 
possessive, or demonstrative pronouns. The students applied rules in forming past time verb to conjunctions. The researcher can conclude that the students still confused in dealing with English grammar systems.

Based on the finding of the analysis above, it shows that Anisa made eleven sentences in 2 minutes 28 seconds. She made eight errors. Dewi made seven sentences in 1 minutes 57 seconds. She made five errors. Fatika made sixteen sentences in 4 minutes 14 seconds. She made eight errors. Fitri made sixteen sentences in 4 minutes 23 seconds. She made seven errors. Ibnu made ten sentences in 2 minutes 18 seconds. He made eight errors. Linda made fiveteen sentences in 3 minutes 7 seconds. She made eight errors. Musli made fourteen sentences in 2 minutes 39 seconds. She made six errors. Nyoman made twelve sentences in 3 minutes 43 seconds. He made nine errors. Pera made ten sentences in 2 minutes 23 seconds. She made seven errors. Sri made fourteen sentences in 6 minutes 34 seconds. She made eleven errors. And about the percentages of errors, here is the data; Anisa: $72,73 \%$ of errors; Dewi: $71,4 \%$ of errors; Fatika: $50 \%$ of errors; Fitri: $43,75 \%$ of errors; Ibnu: $80 \%$ of errors; Linda: $53,3 \%$ of errors; Musli: $42,8 \%$ of errors; Nyoman: $75 \%$ of errors; Pera: $70 \%$ of errors; Sri: $78,57 \%$ of errors. From data of interview, it can be concluded the factors influence of English students' grammatical errors in their speech when their speak using grammar rule. The internal factors are; The first, the students are still difficult to make feeling, for example; confident, feel scary, when they are speaking in public. The 
second, the students are not mastered in their skills. The third, the students are not have many vocabulay, so they can not express their idea to speak. The forth, the students are still think that grammar are not important to speak. For the external factors are; the first, the student can not express their speaking because of their environment or comunity. The second, the teaching-learning process.

\section{CONCLUSION}

According to the findings, it can be concluded that the students have not mastered the use of verb groups. We can see it from the number of the errors made. Although they had been taught about it before, they were still confused which one to use when making a grammatical sentence. It could be because in Bahasa Indonesia we do not have the verb conjugations. We do not have time signaling in expressing ideas. They are unfamiliar to this form and because English is still foreign for them. And those are the possible causes of their errors. The students were still confused in making the agreement between subject and verb. It could be because in Bahasa Indonesia there is no agreement between subject and verb. The students were still confused in differentiating whether to use the definite or indefinite articles. It could be because in Indonesian language grammar there is no definite article used. The students still confused in deciding preposition which preposition should be used, whether to use in, on, or at.

The students over generalized the pluralizing of nouns. They just added the $-\mathrm{s} /$-es without considering that there are some irregular forms of nouns pluralization. The students still 
confused in deciding which pronoun

should be used to substitute nouns,

whether it is personal, relative, possessive, or demonstrative pronouns. The students applied rules in forming past time verb to conjunctions.

From the explanations above, the reseacher can conclude that the students still confused in dealing with English grammar systems.

Based on the finding of the analysis, it shows that Anisa made eleven sentences in 2 minutes 28 seconds. She made eight errors. Dewi made seven sentences in 1 minutes 57 seconds. She made five errors. Fatika made sixteen sentences in 4 minutes 14 seconds. She made eight errors. Fitri made sixteen sentences in 4 minutes 23 seconds. She made seven errors. Ibnu made ten sentences in 2 minutes 18 seconds. He made eight errors. Linda made fiveteen sentences in 3 minutes 7 seconds. She made eight errors. Musli made fourteen sentences in 2 minutes 39 seconds. She made six errors. Nyoman made twelve sentences in 3 minutes 43 seconds. He made nine errors. Pera made ten sentences in 2 minutes 23 seconds. She made seven errors. Sri made fourteen sentences in 6 minutes 34 seconds. She made eleven errors. And about the percentages of errors, here is the data; Anisa: $72,73 \%$ of errors; Dewi: $71,4 \%$ of errors; Fatika: $50 \%$ of errors; Fitri: $43,75 \%$ of errors; Ibnu: $80 \%$ of errors; Linda: $53,3 \%$ of errors; Musli: $42,8 \%$ of errors; Nyoman: $75 \%$ of errors; Pera: $70 \%$ of errors; Sri: $78,57 \%$ of errors. Based on the finding, it can be concluded the factors influence of English students' grammatical errors in their speech when their speak using grammar rule. The internal factors are; The first, the students are still difficult to 
make feeling, for example; confident, feel scary, when they are speaking in public. The second, the students are not mastered in their skills. The third, the students are not have many vocabulay, so they can not express their idea to speak. The forth, the students are still think that grammar are not important to speak. For the external factors are; the first, the student can not express their speaking because of their environment or comunity. The second, the teachinglearning process.

\section{REFERENCES}

Adib, Qowimul (2012). Grammatical Error Analysis on Speaking Competence of English Department Student (A Study At 2010 Speaking Class of ELT Department of Iain Walisongo). Semarang: Education Faculty Walisongo State Institute for Islamic Studies.

Azar, Betty Schrampfer (1996).

Basic English Grammar. New Jersey: Prentice Hall Regents.

Burns, Anne (2010). Doing Action Research in English Language Teaching. p.72. New York and London: Routledge.
Brown, Douglas H (2000). Teaching by Principles: An Interactive Approach to Language Pedagogy (2 $2^{\text {nd }}$ edition). p. 270-271. NY: Addison Wesley, Longman, Inc. (2001). Principles of Language Learning and Teaching (4th edition). p. 7. Longman.

Bailey, Katheleen M (2003). Practical English Language Teaching; Speaking. p. 199. Singapore.

Cohen, Louis (2007). et. al. Research Methods in Education ( $6^{\text {th }}$ edition). p. 168. USA and Canada: Routledge.

Corder, Spit (2003). Error Analysis and Intralingua. p. 10-11. Oxford: Oxford University Press.

Dasiani (2011). An Analysis of the Student Errors in Using Interrogative Sentence at the Second Year of SMP N 2 Batang Hari, East Lampung. Metro: Muhammadiyah University of Metro.

Mulyana, Deddy (2008). Metodologi Penelitian Kualitatif. p. 201. Bandung: PT. Remaja Rosdakarya.

Glenn, Fulcher (2003). Testing Second Language Speaking. p. 23. Britain: Pearson Education Limited.

Mailani Ferianti. The Correlation Between Students' Vocabulary Mastery And Speaking Ability At The Tenth Grade In SMA Muhamadiyah 1 Metro Academic Year 2012/2013. Metro: Muhammadiyah University of Metro.

Marianne, Celce. (2001) et al. Teaching English as a Second 
or Foreign Language. p.58.

Britain: Pearson Education Limited.

Marshall, Catherine (1999).

Designing Qualitative

Research (3 ${ }^{\text {rd }}$ edition). p. 2-3

United States of America:

Sage.

Mc Donough, and Christopher, Shaw (2003). Material and Methods in ELT: A Teacher Guide (2 ${ }^{\text {th }}$ edition). p. 134. UK: Blackwell Publishing.

O'Hair, D., Rubenstein, H., \& Stewart, R. (2007). A pocket guide to public speaking (2nd ed.). p. 3. Boston, MA: Bedford/St. Martin's.

Richards, Jack C (2008). Teaching Listening and Speaking. p.1920. New York: Cambridge University Press.

Scrivener, Jim. Learning Teaching, A Guide Book for English Language Teachers (2nd edition). p. 7. Macmillan Books for Teachers.

Setiyadi, Ag. Bambang. (2006). Teaching English as foreign language. P. 12. Yogyakarta: Graha Ilmu.

Speaking Role at Class. Retrieved, 6 March, 2014 from http://www.sasklearning.gov.sk.ca/d oes/mla /speak.html.

Arikunto, Suharsimi (2007).

Manajemen Penelitian. p.

234. Jakarta: PT. Rineka

Cipta.

Sugiyono (2008). Memahami Penelitian Kualitatif (4th edition). p. 92. Bandung: Alfabeta. (2010). Metode Penelitian Pendidikan Pendekatan Kuantitative, Kualitative dan $R \& D$. Bandung: Alfabeta.
(2011). Metode Penelitian

Pendidikan Pendekatan

Kuantitative, Kualitative dan

$R \& D$. Bandung: Alfabeta.

Telgs, Ricky (2011). Speech Writing and Types of Speeches. p. 5.

Florida: University of Florida, IFAS Extension.

Tim penyusun, (2013). Pedoman penyusunan Proposal Skripsi dan Seminar Program Studi Pendidikan Bahasa Inggris. Metro: Muhammadiyah University of Metro.

Turmudi, Dedi (2013). Getting into Your Writing Product: Developing Essay Writing ( $1^{\text {st }}$ edition). Muhammadiyah University of Metro: UMMPress.

Yuni Sukarti. The Comparison Of Students Speaking By Using Audio Lingual Method Type Chain Drill Technique And Question And Answer Drill Technique At Sma Muhamdiyah 1 Braja Salebah Academic Year 2012/2013. Metro: Muhammadiyah University of Metro. 